NISTIR 8296-05

\title{
NIST Time and Frequency Bulletin
}

Kelsey Rodriguez, Editor

This publication is available free of charge from:

https://doi.org/10.6028/NIST.IR.8296-05

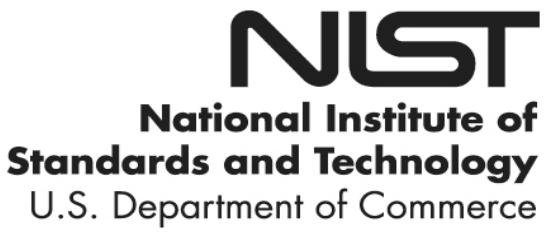




\title{
NIST Time and Frequency Bulletin
}

\author{
Kelsey Rodriguez, Editor \\ Time and Frequency Division \\ Physical Measurement Laboratory
}

This publication is available free of charge from:

https://doi.org/10.6028/NIST.IR.8296-05

May 2020

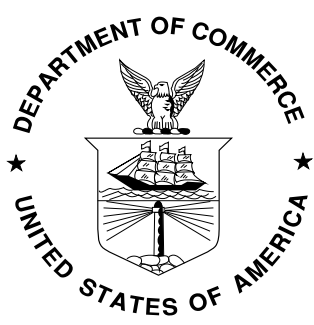

U.S. Department of Commerce Wilbur L. Ross, Jr., Secretary 
NIST TIME AND FREQUENCY BULLETIN

NIST IR 8296-05

No. 749 May 2020

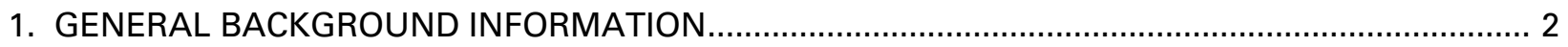

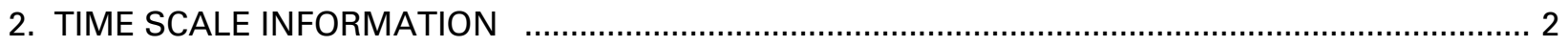

3. BROADCAST OUTAGES OVER FIVE MINUTES AND WWVB

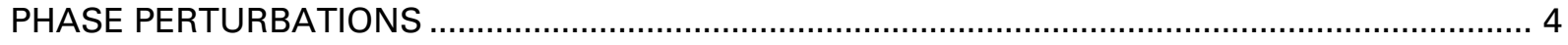

4. NOTES ON NIST TIME SCALES AND PRIMARY STANDARDS …............................................... 4

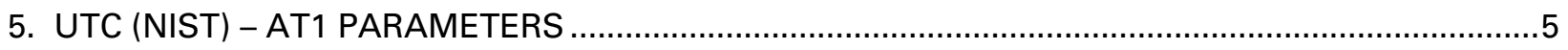

This bulletin is published monthly. Address correspondence to:

Kelsey Rodriguez, Editor

Time and Frequency Division

National Institute of Standards and Technology

325 Broadway MS847

Boulder, CO 80305

(303) 497-5398

Email: kelsey.rodriguez@nist.gov

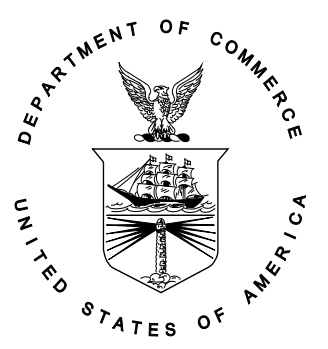

U.S. DEPARTMENT OF COMMERCE, Wilbur L. Ross, Jr., Secretary NATIONAL INSTITUTE OF STANDARDS AND TECHNOLOGY, Walter Copan, NIST Director and Under Secretary of Commerce for Standards and Technology 


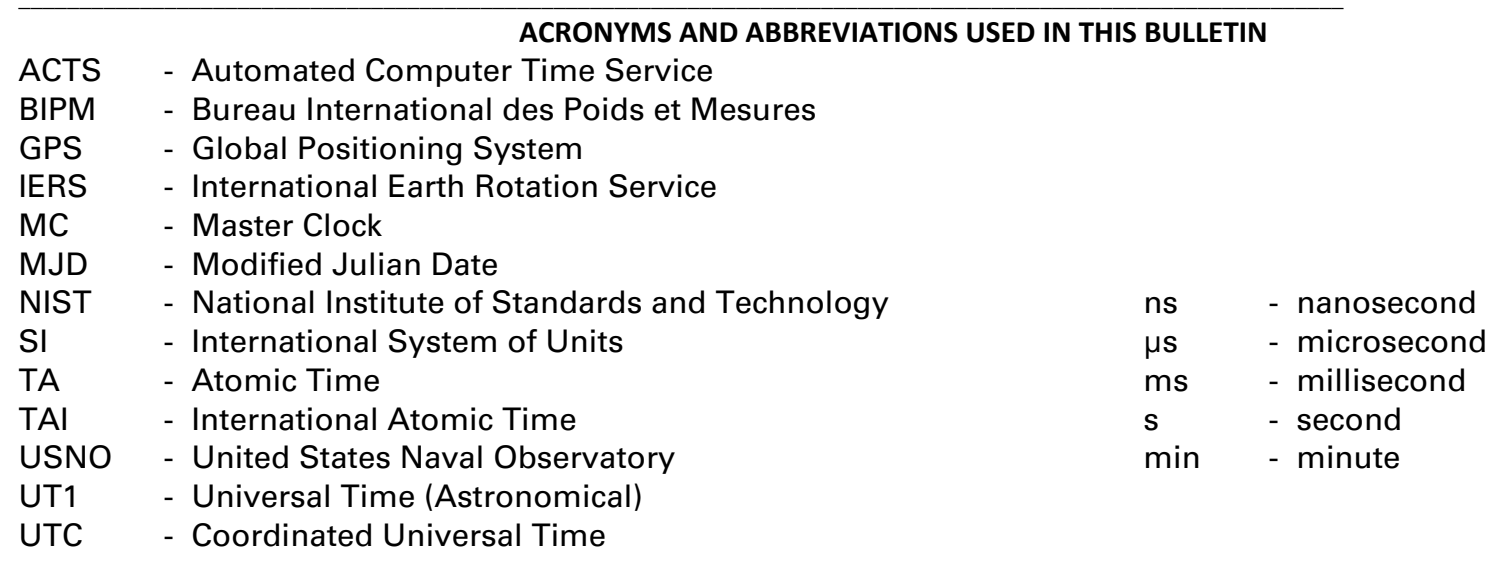

\section{TIME SCALE INFORMATION}

The values listed below are based on data from the IERS, the USNO, and NIST. The UTC(USNO,MC) - UTC(NIST) values are averaged measurements from all available common-view GPS satellites (see bibliography on page 5). UTC - UTC(NIST) data are on page 3.

\begin{tabular}{|c|c|c|c|}
\hline \multicolumn{3}{|c|}{ 0000 HOURS COORDINATED UNIVERSAL TIME } \\
\hline $\begin{array}{c}\text { April } \\
2020\end{array}$ & MJD & $\begin{array}{c}\text { UT1-UTC(NIST) } \\
( \pm 5 \mathrm{~ms})\end{array}$ & $\begin{array}{c}\text { UTC(USNO,MC) - UTC(NIST) } \\
( \pm 20 \mathrm{~ns})\end{array}$ \\
\hline 2 & 58941 & $-225.42 \mathrm{~ms}$ & $-7.1 \mathrm{~ns}$ \\
9 & 58948 & $-233.19 \mathrm{~ms}$ & $-6.1 \mathrm{~ns}$ \\
16 & 58955 & $-238.03 \mathrm{~ms}$ & $-7.1 \mathrm{~ns}$ \\
23 & 58962 & $-240.92 \mathrm{~ms}$ & $-5.5 \mathrm{~ns}$ \\
30 & 58969 & $-242.22 \mathrm{~ms}$ & $-5.5 \mathrm{~ns}$ \\
\hline
\end{tabular}

The master clock pulses used by the WWV, WWVH, and WWVB time-code transmissions are referenced to the UTC (NIST) time scale. Occasionally, $1 \mathrm{~s}$ is added to the UTC time scale. This second is called a leap second. Its purpose is to keep the UTC time scale within $\pm 0.9 \mathrm{~s}$ of the UT1 astronomical time scale, which changes slightly due to variations in the Earth's period of rotation.

NOTE: No leap second was added at the end of December 2019.

Positive leap seconds, beginning at $23 \mathrm{~h} 59 \mathrm{~min} 60 \mathrm{~s}$ UTC and ending at $0 \mathrm{~h} 0 \mathrm{~min} 0 \mathrm{~s}$ UTC, were inserted in the UTC time scale on 30 June 1972, 1981-1983, 1985, 1992-1994, 1997, 2012, 2015 and on 31 December 1972-1979, 1987, 1989, 1990,1995, 1998, 2005, 2008, 2016.

The use of leap seconds ensures that UT1 - UTC will always be held within $\pm 0.9 \mathrm{~s}$. The current value of UT1 - UTC is called the DUT1 correction. DUT1 corrections are broadcast by WWV, WWVH, WWVB, and ACTS and are printed below. These corrections may be added to the received UTC time signals in order to obtain UT1.

$\begin{array}{ll} & -0.2 \text { s beginning } 0000 \text { UTC } 02 \text { May } 2019 \\ & -0.1 \text { s beginning } 0000 \text { UTC } 17 \text { January } 2019 \\ & +0.0 \text { s beginning } 0000 \text { UTC } 21 \text { September } 2018 \\ & +0.1 \text { s beginning } 0000 \text { UTC } 15 \text { March } 2018 \\ & +0.2 \text { s beginning } 0000 \text { UTC } 30 \text { November } 2017 \\ \text { DUT1 = UT1 - UTC = } & +0.3 \text { s beginning } 0000 \text { UTC } 29 \text { June } 2017 \\ & +0.4 \text { s beginning } 0000 \text { UTC } 30 \text { March } 2017 \\ & +0.5 \text { s beginning 0000 UTC } 26 \text { January } 2017 \\ & +0.6 \text { s beginning 0000 UTC } 01 \text { January } 2017 \\ & -0.4 \text { s beginning 0000 UTC } 17 \text { November } 2016\end{array}$


The difference between UTC(NIST) and UTC has been within \pm 100 ns since July 6,1994 . The table below shows values of UTC - UTC(NIST) as supplied by the BIPM in their Circular T publication for the most recent 310-day period in which data are available. Data are given at ten-day intervals. Five-day interval data are available in Circular $T$.

\begin{tabular}{|c|c|c|}
\hline \multicolumn{3}{|c|}{0000 Hours Coordinated Universal Time } \\
\hline DATE & MJD & UTC-UTC(NIST), ns \\
\hline Apr. 30, 2020 & 58969 & -1.7 \\
\hline Apr. 20, 2020 & 58959 & -1.1 \\
\hline Apr. 10, 2020 & 58949 & -0.7 \\
\hline Mar. 31, 2020 & 58939 & -1 \\
\hline Mar. 21, 2020 & 58929 & -0.7 \\
\hline Mar. 11, 2020 & 58919 & 0.1 \\
\hline Mar. 1, 2020 & 58909 & 0.1 \\
\hline Feb. 20, 2020 & 58899 & 1.5 \\
\hline Feb. 10, 2020 & 58889 & 2.2 \\
\hline Jan. 31, 2020 & 58879 & 1.5 \\
\hline Jan. 21, 2020 & 58869 & 0.6 \\
\hline Jan. 11, 2020 & 58859 & -2 \\
\hline Jan. 1, 2020 & 58849 & -0.8 \\
\hline Dec. 22, 2019 & 58839 & 2.8 \\
\hline Dec. 12, 2019 & 58829 & 1.2 \\
\hline Dec. 2, 2019 & 58819 & 0.4 \\
\hline Nov. 22, 2019 & 58809 & 0.7 \\
\hline Nov. 12, 2019 & 58799 & 0.1 \\
\hline Nov. 2, 2019 & 58789 & 0.8 \\
\hline Oct. 23, 2019 & 58779 & 2.4 \\
\hline Oct. 13, 2019 & 58769 & 1.1 \\
\hline Oct. 3, 2019 & 58759 & 0.6 \\
\hline Sep. 23, 2019 & 58749 & 1.1 \\
\hline Sep. 13, 2019 & 58739 & 1 \\
\hline Sep. 3, 2019 & 58729 & 0.6 \\
\hline Aug. 24, 2019 & 58719 & 0.3 \\
\hline Aug. 14, 2019 & 58709 & -0.1 \\
\hline Aug. 4, 2019 & 58699 & -0.1 \\
\hline July 25, 2019 & 58689 & 1.2 \\
\hline July 15, 2019 & 58679 & 1.2 \\
\hline July 5, 2019 & 58669 & 0.7 \\
\hline June 29, 2019 & 58659 & -1.9 \\
\hline June 15, 2019 & 58649 & -3.6 \\
\hline
\end{tabular}


3. BROADCAST OUTAGES OVER FIVE MINUTES AND WWVB PHASE PERTURBATIONS

\begin{tabular}{|c|c|c|c|c|c|c|c|c|c|}
\hline \multicolumn{6}{|c|}{ OUTAGES OF 5 MINUTES OR MORE } & \multicolumn{4}{|c|}{$\begin{array}{c}\text { PHASE PERTURBATIONS } \\
2 \mathrm{~ms}\end{array}$} \\
\hline Station & $\begin{array}{c}\text { Apr } \\
2020\end{array}$ & MJD & $\begin{array}{c}\text { Began } \\
\text { UTC }\end{array}$ & Ended UTC & Freq. & $\begin{array}{l}\text { Apr } \\
2020\end{array}$ & MJD & $\begin{array}{c}\text { Began } \\
\text { UTC }\end{array}$ & $\begin{array}{l}\text { End } \\
\text { UTC }\end{array}$ \\
\hline WWVB & $\begin{array}{l}26 \\
27 \\
28 \\
\end{array}$ & $\begin{array}{l}58965 \\
58966 \\
58967\end{array}$ & $\begin{array}{l}0030 \\
0411 \\
0353 \\
\end{array}$ & $\begin{array}{l}0124 \\
0430 \\
0411 \\
\end{array}$ & $\begin{array}{l}60 \mathrm{kHz} \\
60 \mathrm{kHz} \\
60 \mathrm{kHz}\end{array}$ & None & & & \\
\hline WWV & None & & & & & None & & & \\
\hline WWVH & None & & & & & None & & & \\
\hline
\end{tabular}

\section{NOTES ON NIST TIME SCALES AND PRIMARY STANDARDS}

Primary frequency standards developed and operated by NIST are used to provide accuracy (rate) input to the BIPM and to provide the best possible realization of the SI second. NIST-F1 and NIST-F2, cold-atom cesium fountain frequency standards, have served as the U.S. primary standards of time and frequency since 1999. The uncertainty of NIST-F2 is currently about 1 part in $10^{16}$.

The AT1 scale is run in real-time by use of data from an ensemble of cesium standards and hydrogen masers. It is a free-running scale whose frequency is maintained as nearly constant as possible by choosing the optimum weight for each clock that contributes to the computation.

UTC is generated at the BIPM by use of a post-processed time-scale algorithm and is not available in real-time. The parameters that we use to generate UTC(NIST) in real-time are therefore based on an extrapolation of UTC from the most recent available data.

UTC(NIST) is generated as an offset from our real-time scale AT1. Time steps are never used. Instead, the frequency is steered so that the time output remains close to UTC. This is accomplished by using data published by the BIPM in its Circular $T$ and by weekly estimates of UTC, which are published by the BIPM as rapid UTC or UTCr. Changes in the frequency may be made as often as once per week and are limited to $\pm 2.3 \times 10^{-14}$. The frequency of UTC(NIST) is kept as stable as possible at other times.

\section{References:}

Allan, D.W.; Hellwig, H.; and Glaze, D.J., "An accuracy algorithm for an atomic time scale," Metrologia, Vol.11, No.3, pp. 133-138 (1975).

Allan, D.W.; Davis, D.D.; Weiss, M.A.; Clements, A.; Guinot, B.; Granveaud, M.; Dorenwendt, K.; Fischer, B.; Hetzel, P.; Aoki, S.; Fujimoto, M.; Charron, L.; and Ashby, N., "Accuracy of international time and frequency comparisons via global positioning system satellites in common-view," IEEE Transactions on Instrumentation and Measurement, Vol. IM-34, pp.118-125 (1985).

Heavner, T.P.; Jefferts, S.R.; Donley; E.A.; Shirley, J.H. and Parker, T.E., "NIST F1; recent improvements and accuracy evaluations," Metrologia, Vol. 42, pp. 411-422 (2005).

Jefferts, S.R.; Shirley, J.; Parker, T.E.; Heavner, T.P.; Meekhof, D.M.; Nelson, C., Levi, F.; Costanza, G.; De Marchi, A.; Drullinger, R.; Hollberg, L.; Lee, W.D.; and Walls, F.L., "Accuracy evaluation of NIST-F1," Metrologia, Vol. 39, pp. 321336 (2002).

Lewandowski, W. and Thomas, C., "GPS Time transfer," Proceedings of the IEEE, Vol. 79, pp. 991-1000 (1991).

Parker, T.E.; Jefferts, S.R.; Heavner, T.P.; and Donley, E.A., "Operation of the NIST-F1 caesium fountain primary frequency standard with a maser ensemble, including the impact of frequency transfer noise," Metrologia, Vol. 42, pp. 423-430 (2005). 
Weiss, M.A.; Allan, D.W., "An NBS Calibration Procedure for Providing Time and Frequency at a Remote Site by Weighting and Smoothing of GPS Common View Data," IEEE Transactions on Instrumentation and Measurement, Vol. IM-36, pp. 572-578 (1987). 


\section{UTC(NIST) - AT1 PARAMETERS}

The table below lists parameters that are used to define UTC(NIST) with respect to our real-time scale AT1. To find the value of UTC(NIST) - AT1 at any time $T$ (expressed as a Modified Julian Date, including a fraction if needed), the appropriate equation to use is the one for which the desired $T$ is greater than or equal to the entry in the $T_{0}$ column and less than the entry in the last column. The values of $x_{\mathrm{ls}}, x$, and $y$ for that month are then used in the equation below to find the desired value. The parameters $x$ and $y$ represent the offsets in time and frequency, respectively, between UTC(NIST) and AT1; the parameter $x_{\text {is }}$ is the number of leap seconds applied to both UTC(NIST) and UTC, as specified by the IERS. Leap seconds are not applied to AT1.

\begin{tabular}{|c|c|c|c|c|c|}
\hline \multicolumn{6}{|c|}{ UTC(NIST) - AT1 $=x_{\mathrm{Is}}+x+y\left(T-T_{0}\right)$} \\
\hline Month & $\begin{array}{l}x_{\text {Is }} \\
(\mathrm{s})\end{array}$ & $\begin{array}{c}x \\
(\mathrm{~ns})\end{array}$ & $\begin{array}{c}y \\
\text { (ns/d) }\end{array}$ & $\begin{array}{c}T_{0} \\
(\mathrm{MJD})\end{array}$ & $\begin{array}{l}\text { Valid until } 0000 \text { on: } \\
\text { (MJD) }\end{array}$ \\
\hline Apr 20 & -37 & -483793.85 & -37 & 58940 & 58970 \\
\hline Mar 20 & -37 & -482646.85 & -37 & 58909 & 58940 \\
\hline Feb 20 & -37 & -482535.85 & $-37.00+$ & 58906 & 58909 \\
\hline Feb 20 & -37 & -482020.65 & $-36.80 \dagger$ & 58892 & 58906 \\
\hline Feb 20 & -37 & -481576.65 & -37 & 58880 & 58892 \\
\hline Jan 20 & -37 & -481243.65 & -37.00 & 58871 & 58880 \\
\hline Jan 20 & -37 & -480465.95 & $-36.80+$ & 58850 & 58871 \\
\hline Jan 20 & -37 & -480429.45 & -36.50 & 58849 & 58850 \\
\hline $\operatorname{Dec} 19$ & -37 & -480210.45 & $-36.50 \dagger$ & 58843 & 58849 \\
\hline Dec 19 & -37 & -479989.95 & $-36.75 t$ & 58837 & 58843 \\
\hline Dec 19 & -37 & -479284.10 & -37.15 & 58818 & 58837 \\
\hline Nov 19 & -37 & -478912.60 & $-37.15 \dagger$ & 58808 & 58818 \\
\hline Nov 19 & -37 & -478389.70 & $-37.35 \dagger$ & 58794 & 58808 \\
\hline Nov 19 & -37 & -478167.40 & $-37.05^{*}$ & 58788 & 58794 \\
\hline Oct 19 & -37 & -477871.00 & -37.05 & 58780 & $58788^{*}$ \\
\hline Oct 19 & -37 & -477011.95 & -37.35 & 58757 & $58780 \dagger$ \\
\hline Sep 19 & -37 & -475891.45 & -37.35 & 58727 & 58757 \\
\hline Aug 19 & -37 & -474995.05 & -37.35 & 58703 & 58727 \\
\hline Aug 19 & -37 & -474735.35 & -37.10 & 58696 & $58703 \dagger$ \\
\hline Jul 19 & -37 & -473696.55 & -37.10 & 58668 & 58696 \\
\hline Jul 19 & -37 & -473584.35 & -37.40 & 58665 & $58668 \dagger$ \\
\hline Jun 19 & -37 & -473172.95 & -37.40 & 58654 & 58665 \\
\hline Jun 19 & -37 & -472949.75 & -37.20 & 58648 & $58654 \dagger$ \\
\hline Jun 19 & -37 & -472469.4 & -36.95 & 58635 & $58648 \dagger$ \\
\hline May 19 & -37 & -471878.2 & -36.95 & 58619 & 58635 \\
\hline May 19 & -37 & -471327.7 & -36.70 & 58604 & $58619 \dagger$ \\
\hline Apr 19 & -37 & -471107.5 & -36.70 & 58598 & 58604 \\
\hline Apr 19 & -37 & -470592.3 & -36.80 & 58584 & $58598 \dagger$ \\
\hline Apr 19 & -37 & -470222.3 & -37.00 & 58574 & 58584† \\
\hline Mar 19 & -37 & -470074.3 & -37.00 & 58570 & 58574 \\
\hline Mar 19 & -37 & -469817.05 & -36.75 & 58563 & $58570 \dagger$ \\
\hline
\end{tabular}

\section{† Rate change in mid-month}

*Provisional value 